\title{
Internalisation of Character Values in Learning at Institution of English Course
}

\author{
Djum Djum Noor Benty \\ Department of Educational Administration \\ Universitas Negeri Malang, Indonesia \\ djum.djum.fip@um.ac.id
}

\author{
Yuyik Lulita Sari \\ Department of Educational Administration \\ Universitas Negeri Malang, Indonesia \\ yuyik.lulitasarie@gmail.com
}

\author{
Ahmad Nurabadi \\ Department of Educational Administration \\ Universitas Negeri Malang, Indonesia \\ Email: ahmad.nurabadi.fip@um.ac.id
}

\begin{abstract}
The purpose of this study was to describe internalization of character values. This study used a qualitative approach. Data was collected by observation, interview, and documentation studies. The results of the study were: (1) support they have in internalizing character values namely warning statement and giving prerogative or authority in the form of expenditure of students who do not want to be regulated, (2) constraints faced include: education in the family that implements minimal rules, lack of commitment of students to want to be regulated, education in educational institutions that implement minimal rules, variations in the age of students, intention to participate students who change, and the intention or motivation of learners to learn, (3) strategy used in utilizing support is to be wise, and (4) strategies used in overcoming obstacles, namely with a personal (face to face) approach while being advised, making an agreement with students, and introspection.
\end{abstract}

Keywords: internalization, character values

\section{INTRODUCTION}

Character is ownership of good things (Lickona, 2012). 'Good' can be interpreted as moral values that have objective goodness, namely values that strengthen human dignity and promote the goodness of individuals and society (Lickona, 2012). Character is good values (know goodness, want to do good, real good life, and have good impact on the environment) which are selfcontained and embodied in behavior (National Character Development National Policy 2010-2025, 2010). So, character is a quality that distinguishes between someone who is civilized and not. Whereas, someone is said to have character when he has fulfilled four things, namely knowing good value, wanting to do good, being consistent in doing good deeds, and having a good impact on the environment.

Character society is a future asset of a nation/country. Cicero (in Lickona, 2012) said that in the character of society, the welfare of the nation lies. Deeper, the Indonesian government through the National Character Development Policy of 2010-2025 (2010) stressed that the loss of character causes the loss of the nation's next generation. Based on the two quotations, it is clear that seeking for a society to grow and develop into a character with character is an absolute thing that must be done by a nation/country including Indonesia, because only in the character of society, the future of a nation/country can be entrusted . In fact, the health of a nation in the next few centuries, said Lickona (2012) depends on how serious the community is to commit to this calling.

Course are educational institutions outside the school that provide lessons and knowledge or skills in a short time. As one form of non-formal education unit, the course functions as a substitute, enhancer, and complementary to formal education in order to support lifelong education (Law Number 20 of 2003). Courses are held for people who need knowledge, skills, life skills, and attitudes to develop themselves, develop their profession, work, independent business, or continue their education to a higher level (Law Number 20 of 2003). Although the function of the course is as a substitute/supplement/complement to formal education, courses as a sub-system of national education still have the same function as an education unit in the formal pathway in building and forming Indonesian human beings who have one faithful, intelligent, and have good personal qualities (character).

Basic English Course or commonly abbreviated as $\mathrm{BEC}$ is an English language education institution founded by Mr. Muhammad Kalend Osen on June 15, 1977 with an address on street of Anyelir Number 8 RT 01 RW XII, Singgahan, Palem, Pare, Kediri, East Java. Growing and developing as a non-formal education unit, BEC appears as a well-known English course institution in the Pare environment. Aside from being touted as the oldest English language course institution (in Pare) as well as the pioneer of the birth of 'English Village Pare', BEC is also known as an Islamic language course with a strong Islamic nuance, so that there is a nickname 'a course with pesantren taste'. BEC is also known as an institution that is firm and consistent in disciplining its students. In fact, the firmness of BEC educational institutions in applying discipline to trigger the emergence of public judgment that violates the discipline of BEC means ready to be expelled from BEC.

\section{METHOD}

The approach used in this study is a qualitative approach with the aim of obtaining descriptions and descriptions of the internalization of character values. This approach was chosen because the focus in this study relates to relationships and processes so that it requires observation. The type of research used in this study is a case study, which focuses on humans and events. The role of the researcher as a data collector and observer to 
understand the conditions and obtain information directly at the Educational Institution of the Basics English Course Pare, Kediri, Province of East Java.

Sources of data were obtained from key informants, namely the director of the Basic English Course, supported by information from educators and education. The process of collecting data is done by researchers by applying observation, interview, and documentation studies techniques. Then analyzed based on the process of interactive data analysis according to Miles and Huberman which consists of three steps, namely: data reduction, data display, and verification of data or conclusions. The data obtained, checked its validity by: (1) extending the time of research, (2) increasing the research informants, (3) increasing perseverance and thoroughness, (4) triangulating data sources, and (5) utilizing the research documents obtained/owned.

\section{RESULTS}

Support Owned in Internalisation of Character Values There are two supports that BEC TPK has in internalizing character values at BEC. First, is the warning statement of Mr. Kalend, who emphasized that anyone (BEC students) who did not want to be regulated, was excluded from BEC. Second, is the granting of prerogative or authority by Mr. Kalend to BEC TPK to provide decisive action in the form of student expenditures that do not want to be regulated from BEC. Both of these supports, explicitly known through the statement of Ms. Nova, said that the answer from $\mathrm{Mr}$. Kalend also remained like that before, he gave us the right, if indeed it cannot be arranged, it would be issued please, for example one class is like there are only five people. No, the most important thing can be arranged and Mr. Ibnu said that actually each of us was given a policy to regulate, if for example there was a child who could not be a diator, it could be issued, without having to discuss with the teacher. If they don't accept it, they may complain to Mr. Kalend, like that.

\section{Constraints Faced}

The obstacles faced by BEC TPK in internalizing character values to students at BEC are as follows. First, according to the statement of Mam Nova, which is a problem, in my opinion, during this time I have faced it when they were, children who came from maybe their families or maybe from themselves who were indeed rather difficult to manage. So the types of children who have previously gained tremendous freedom, so here, maybe it is rather difficult to follow the rules. Based on this information, it is known that the constraints faced by Mam Nova in internalizing character values at BEC are families with minimal rules so that children tend to get freedom with high intensity and lack of commitment in students to be regulated. The same obstacle was also expressed by Mr. Khoirul and Mr. Sali.

Second, according to Mr. Adin is the obstacle of the student himself. If from students, actually, one, most of the students are not ready to accept the rule, so the rules applied, according to them, are hard, because before he was at Be-E-Se, maybe nine taons or maybe twelve years, he have been educated in other institutions that are not as hard as those in Be-E-Se, like that. Especially the problem of education, not hard on the material, right, but on education, especially the problem of discipline, that. Based on Mr. Adin, it is known that the obstacles faced by $\mathrm{Mr}$. Adin in internalizing character values at BEC, aside from the lack of commitment in students to be regulated, the problem is the discipline of discipline received by students from educational institutions before studying at BEC which is considered not as hard as those at BEC. The same obstacle was also expressed by $\mathrm{Mr}$. Ibnu.

Third, according to Mr. Fa that is if the problem is, age segmentation for example. For certain periods, indeed we have a system that is patent, for example, yes, and it works successfully, but if it succeeds in one period, it is brought to another period, not necessarily successful, because there are ages certain those who sometimes absorb it are not the same, if they are adults, the absorption is good, if they learn about those values, but if the child or the graduate of eS-eM-A must be shown 'this, this, this', so. That's usually the problem. So, there needs to be panismen, the panismen riwhet is too. So, the calorie when our problem says 'good', 'thank you', etc., yes the form is verbal, but if it's panic, yes, we advise, not until we drop them, right? Based on $\mathrm{Mr}$. Fa, it is known that the obstacles faced by $\mathrm{Mr}$. Fa in internalizing character values at BEC is the variation in the age of students, which is closely related to the maturity level of students in receiving lessons about values. The same obstacle was also expressed by Mr. Sali and Mam Nunung.

Fourth, according to Mr. Khoirul, that is, it is possible that the intention has also changed. Based on Mr. Khoirul, it is known that the obstacles faced by $\mathrm{Mr}$. Khoirul in internalizing character values at BEC is the intention of learners who change, from the beginning is to learn, but over time, that intention changes which is no longer focusing on the intention to learn. Fifth, according to Mr. Rozaq namely yes, because the background of people is different. What I learned from those children. First, their motivation is clear, which affects how they behave here later, that is very clear. Kalok, whose motivation really comes from...really from him himself, surely that person is going to be, his language is 'obedient', yes, surely that is, I confirm that. And there are also those who...go along with it. Yes, those two people were. If the motivation comes from ourselves, we want to be therapeutic, what is it that is accepted to him, it's easy, and the person must be a manot, I pay attention. Well...this is different, the motivation came because he joined in. Participation is also still divided again, first, follow the group, then follow his girlfriend, yes it is there. That, two I know. Then there is also the third one, who came from his parents or whose parents ex from Bi-I-Si, and who applied his child must also take part in Bi-I-Si. Well, sometimes, the child is not in accordance with his parents. Well these two are usually difficult to direct, because he, sometimes here, because they are separated from his parents, so, he motivated him to learn, his motivation to learn it, lose the same as he wants to be free, rah-rah like that, more like that. It must be him, more use of time to gather, play like that, often like that. So, the obstacle is that, people who are indeed motivated to learn are lacking, because it is not their desire to come to Be-E- 
Se on their own initiative, like that. Based on Mr. Rozaq, it is known that the obstacles faced by Mr. Rozaq in internalizing character values at BEC is the intention of students in this case is to refer to the basic motivation of students studying at BEC, such as: self-desire/coercion of parents/following friends or girlfriends.

\section{Strategy used in utilizing support}

The strategy used by BEC TPK in utilizing the support they have in internalizing character values to students at BEC is to be wise. That is, even though BEC TPK were given prerogative or authority by Mr. Kalend to provide decisive action in the form of expenditure of students who do not want to be regulated from BEC as a manifestation of Mr. Kalend to BEC TPK in the interests of enforcing discipline as Mr. Kalend points out in his warning statement, BEC TPK did not want to apply arbitrarily or arbitrarily in using their rights or authority. In using their rights and authority, BEC TPK are known to hold to the guideline that while students (who are in trouble) can still be advised/directed/ guided to improve themselves for the mistakes or problems that they have made or create which are shown in good faith participants students concerned to behave, behave, and act 'good' (example: from being late to being late in class, from not speaking English to wanting to speak English, from often being negligent, etc.), then these rights and authorities will not be used by BEC TPK. Expressed by Mr. Rozaq that just yes we are, like, are given the power like that, no...it's not really like that, really must, really you, when you don't do this, to your students, like that. Jadih, really the stock is indeed a must have been released, it really is a fatal mistake like that. Well, the fatal one was already told by Mr. Kalend. First, that is clear, the writing 'when he doesn't want to be regulated', is that clear.

\section{Strategies Used in Overcoming Obstacles}

The strategies used by BEC TPK in overcoming the obstacles faced in internalizing character values to students at BEC are as follows. First, according to the statement of Mam Nova, namely if, my personally, when for example I see a child that I mean to be my protégé, how come I have problems with discipline, I call it, immediately call it, which means talking about it directly without having to tell the others, which means we directly communicate with concerned 'why can it be like this', for example 'why is it difficult to dress as applied here, the reason why?'. We need to know too, and later we will provide guidance or explanations related to everything in Be-E-Se. Based on the information of Mam Nova, it is known that the strategy used by Mam Nova in managing the obstacles faced in internalizing character values to students at BEC is to take a personal approach in the form of calling on students (who are in trouble) to speak privately (face to face) while being advised. The same strategy was also expressed by Mr. Ibn, Mr. Rozaq, Mr. Khoirul, Mr. Fa, Mam Atun, and Mr. Sali.

Second, according to Mr. Khoirul namely make a deal first. We make commitments with them or making a dael. Well...so, before we...indeed when we first met, after meeting with mister Kalend, we had time in class, a meeting too. We make an agreement also, 'not to be bored like how late, how'. We make rules again, more specifically in class. If I, especially my class, if they are five minutes late, stand five minutes, if it's ten minutes late, stand ten minutes, if it's fifteen minutes late, already, then I invite you to come back tomorrow. So, children...they don't want to, they are embarrassed if they violate, shame themselves. So, thank God, they want to follow what we have made, discipline agreement. Based on Mr. Khoirul, it is known that the strategy used by Mr. Khoirul in managing the obstacles faced in internalizing character values to students at BEC is to make agreements/commitments/make a deal (within the scope of the classroom) with the students. The same strategy was also expressed by Mam Nunung.

Third, according to Mr. Adin, that is, we think positively, actually the mistake is not the fault of the child, but this is a mistake than ourselves, maybe it is less close to the children, so children assume that this is normal, that is. So, my personal feelings, back to ourselves, introspection, and trying to find ways to let the child realize and understand that all the obstacles that we have conveyed through the rules or maybe tarjet-tarjet so on, really make they realize that what we are teaching is actually not for ourselves but for them. Based on Mr. Adin this, it is known that the strategy used by Mr. Adin in managing the obstacles faced in internalizing character values to the students at BEC is self-introspection or selfawareness with the consideration that perhaps the location of the problem arises (such as: students are late in class, there are still TC students who speak Indonesia, etc.) is in the educator's self (such as: the lack of openness of educators with students so that it is difficult to build closeness between the two, which is very influential on the attitudes of students' attention to what is taught by educators, including the character values). The same strategy was also expressed by $\mathrm{Mr}$. Fa.

\section{DISCUSSION}

Support Owned in Internalisation of Character Values There are two supports that BEC TPK has in internalizing character values at BEC. First, is the warning statement of Mr. Kalend which is the basis of learning at BEC which confirms that anyone (BEC students) who do not want to be regulated, then is excluded from BEC. Second, is the granting of prerogative or authority by Mr. Kalend to BEC TPK to provide decisive action in the form of student expenditures that do not want to be regulated from BEC.

If combined with the results of previous studies conducted by Widiasari (2013) which found that the supporting factors in the transformation of the culture of discipline of students in SMK PGRI 3 Malang are clear rules, examples from educators, supporting facilities, and information technology that the school has already advanced, the similarity between support in the cultural transformation of disciplines of students at SMK PGRI 3 Malang and support in internalizing character values at BEC Pare Kediri is located in the existence of clear rules. Whereas, when combined with the results of research conducted by Herfianto (2014) who found that the supporting factors for character education management at SD Islam Surya Buana Malang included collaboration between educators, participation of students and parents of students. The form of support from principals and 
educators to achieve the success of character education at Surya Buana Islamic Elementary School in Malang includes principals and educators working together to foster and supervise students in schools to achieve the goal of forming the character of students who have moral character, the similarity between support in character education management at Surya Buana Islamic Elementary School Malang and support in internalizing character values at BEC Pare Kediri is located in good cooperation between the institution leadership and the institution TPK.

Next, when combined with the results of research conducted by Rachmawati (2018) who found that supporting factors in implementing the implementation of a school-based culture include supporters from internal parties and external parties. Supporting factors from internal parties are educators who oversee school culture, order all elements for the successful implementation of culture, supporting school facilities and school culture and balanced learning. Supporting factors from external parties are cooperation with the Naval Base, simulator facilities from the DPR, collaboration with the Bahrul Magfiroh Islamic Boarding School, UIN Mubhaligh, and Christian Dormitory for religious education, and supporting parents in school culture, the similarities between support in implementing the Cultural Based School Culture in Character Formation of Students (Case Study at SMK Negeri 13 Malang) and support in internalizing character values at BEC Pare Kediri is located in the commitment of educators in their participation in enforcing the rules regarding teaching values and disciplined behavior of all elements in the institution.

\section{Constraints Faced}

Some of the obstacles that were faced by BEC

TPK in internalizing character values at BEC, among others: (1) education received by students in the family, in this case is a family that applies minimal rules specifically related to discipline, (2) the lack of commitment of students to be regulated, while 'want to be regulated' itself is a moral prerequisite to be able to study at BEC, (3) education received by students in educational institutions before studying at BEC, in this case educational institutions who apply minimal rules, especially those related to discipline, (4) the age variation of students where this is closely related to the maturity level of students in receiving lessons about the value given to them, (5) the intention of students to change, from the initial is to learn, but over time, that intention changes which is no longer focusing on the intention to learn, and (6) the intention of students in this case is to refer to the basis of motivation of students learning at BEC, such as: self-desire/coercion of parents/following friends or girlfriends.

If combined with the results of previous studies conducted by Widiasari (2013) which found that the obstacles in the transformation of disciplinary culture of students in SMK PGRI 3 Malang were parents who did not understand the school vision and did not know the variables of child delinquency, lack of awareness of some students towards culture discipline, the similarities between the constraints in the transformation of disciplinary culture of students at SMK PGRI 3 Malang and the constraints in internalizing character values at BEC Pare Kediri are located in the lack of commitment of students to discipline. Whereas, when combined with the results of research conducted by Herfianto (2014) who found that the inhibiting factors of character education at the Surya Surya Buana Islamic Elementary School include problems in planning, process, and evaluation. The problem in planning is that there is no benchmark for determining values in assessing character education so educators also have difficulty in making activities that support the character of students according to the school's vision, mission, and goals. Factors inhibiting character education in its implementation include students who pay less attention to the lesson and are less orderly in complying with school rules. The inhibiting factor in character education assessment includes the absence of a benchmark in assessing character education, the similarities between constraints in character education management at Malang Surya Buana Elementary School in Malang and the constraints in internalizing character values at BEC Pare Kediri are located in the lack of commitment of students to disciplined.

Next, when combined with the results of research conducted by Rachmawati (2018) who found that the inhibiting factors in the implementation of a culture-based school culture included obstacles from internal parties and external parties. Inhibiting factors from internal parties are some educators who violate commitments, students who are less able to build school locations are difficult to access. Inhibiting factors from external parties, namely parents who do not make good habits at home, the similarities between the obstacles in the implementation of the School Culture Based on Characteristics of Student Character Formation (Case Study at SMK Negeri 13 Malang) and constraints in internalizing character values in BEC Pare Kediri is located in the lack of commitment of students to be disciplined and educated in families that implement minimal rules.

\section{Strategy used in utilizing support}

The strategy used by BEC TPK in utilizing the support they have in internalizing character values to students at BEC is to be wise. That is, even though BEC TPK were given prerogative or authority by Mr. Kalend to provide decisive action in the form of expenditure of students who do not want to be regulated from BEC as a manifestation of Mr. Kalend to BEC TPK in the interests of enforcing discipline as Mr. Kalend points out in his warning statement, BEC TPK did not want to apply arbitrarily or arbitrarily in using their rights or authority. In using their rights and authority, BEC TPK are known to hold to the guideline that while students (who are in trouble) can still be advised / directed / guided to improve themselves for the mistakes or problems that they have made or create which are shown in good faith participants students concerned to behave, behave, and act 'good' (example: from being late to being late in class, from not speaking English to wanting to speak English, from often being negligent, etc.), then these rights and authorities will not be used by BEC TPK.

The strategy of being wise used by BEC TPK in utilizing the support they have in internalizing character 
values to the students at BEC is in line with the internalization process that is associated with fostering the students proposed by Muhaimin (1996) that there are three stages that represent the process of internalization, namely: (1) the stage of value transformation which is a process carried out by educators in informing good and bad values where at this stage only verbal communication occurs between educators and students, (2) the transaction value stage is a the stage of value education by carrying out two-way communication between educators and students in the form of reciprocal interaction, and (3) the stage of trans-internalization which is a stage that is far more profound than the stage of transactions where at this stage not only verbal communication but also attitudes mental and personality, at the stage this personality communication plays an active role.

\section{Strategies Used in Overcoming Obstacles}

The several things used by BEC TPK as a strategy in overcoming the obstacles faced in internalizing character values to students at BEC include: (1) personal approach in the form of calling on students (who are in trouble) to speak privately (face to face) as advised, (2) making agreements/ commitments/make a deal (within the scope of the class) with students, and (3) selfintrospection or introspection with consideration that perhaps the location or base of the emergence of problems (such as: students are late in class, there are still TC students who speak Indonesian, etc.) are in themselves educators (such as: lack of open educators with students so it is difficult to build closeness between the two which is very influential on attitudes of attention learners will be taught by educators, including questions about character values).

If combined with the results of previous studies conducted by Widiasari (2013) who found that the efforts made to overcome obstacles in the transformation of disciplinary culture of students in SMK PGRI 3 Malang were maximizing coordination with parents of students and maximizing homeroom functions to carry out their functions of giving counseling, the similarities between the strategies used in overcoming obstacles in the transformation of disciplinary culture of students in SMK PGRI 3 Malang and the strategies used in overcoming obstacles in internalizing character values at BEC Pare Kediri are located in the efforts of educators to make a personal approach to students (who are in trouble) to provide advice/counseling. Whereas, when combined with the results of research conducted by Rachmawati (2018) who found that the solutions taken to overcome obstacles in the implementation of a culture-based school culture included solutions from internal parties and external parties. Solutions to overcome obstacles from internal parties, namely the implementation of school evaluations, gradual handling of all elements, cadets' pocket books for students, penalties for violations, and the existence of school dormitories. The solution to overcoming obstacles from external parties is socialization activities with parents, the similarities between strategies used in overcoming constraints in implementing the Learning-Based School Culture in Character Formation of Students (Case Study at SMK Negeri 13 Malang) and strategies used in overcoming obstacles in internalizing character values at BEC Pare Kediri is located in the implementation of the consequences for students who violate the rules where if at BEC Education Institution this is realized in the form of educators making agreements/commitments/make a deal (within the scope class) with the students in which the agreement is discussed about the rules applied and the consequences that will be obtained if it violates the rules, while if at SMK Negeri 13 Malang this is manifested in the form of punishment for each violation case.

\section{CONCLUSION}

The conclusions of the study show: (1) the support they have in internalizing character values is a warning statement to Mr. Kalend and the granting of prerogative or authority in the form of student expenditures that do not want to be regulated by BEC, (2) constraints faced in internalizing character values include: education in families that implement minimal rules, lack of commitment of students to be regulated, education in Educational Institutions that implement minimal rules, variations in the age of students, the intention of students to change, and the intention or motivation of learners at BEC, (3) the strategies used in utilizing support are to be wise, and (4) strategies used in Overcoming obstacles is a personal (face to face) approach while being advised, making agreements with students, and doing selfintrospection.

\section{REFERENCES}

[1] Akbar, A. I. 2000. Character Education. USA: Harvard University.

[2] Elfindri, M. Basri, W., Poltak, T., Fitri, Y., Elfa, E. Z., \& Ristapawa, I. 2010. Soft Skills for Educators. Jakarta: Baduose Media.

[3] Hariadi. 2009. Soft Skill and Student Creativity Program. Campus Generation, 2 (2), 119-134.

[4] Herfianto, F. D. 2014. Character Education Management at SD Islam Surya Buana Malang. Unpublished thesis. Malang: FIP Malang State University.

[5] Ministry of Education and Culture. 2011. Anti-Corruption Education for Universities. Jakarta: Ministry of Education and Culture.

[6] Kurniati, I. 2007. Success Factor, (Online), (www.pangudiluhur.org), accessed March 11, 2017.

[7] Lickona, T. 2012. Character Matters. Juma A. W. Translation Jakarta: PT Earth Literacy.

[8] Muhaimin. 1996. Teaching and Learning Strategies. Surabaya: Media Image.

[9] Government of the Republic of Indonesia. 2006. Law of the Republic of Indonesia Number 20 of 2003 concerning the National Education System. Bandung: Fokus Media.

[10] Development of Cultural and National Character Education School Guidelines for 2010. Reforming Teachers (online), (http://gurupembaharu.com), accessed January 20, 2016.

[11] Rachmawati, W. 2018. School Culture Based on Characteristics in Character Formation of Students (Case Study at SMK Negeri 13 Malang). Unpublished thesis. Malang: FIP UM.

[12] Suryana. 2006. Entrepreneurship. Jakarta: PT Salemba Empat.

[13] Widiasari, D. 2013. Transformation of Discipline Culture of Students at SMK PGRI 3 Malang. Unpublished thesis. Malang: FIP UM. 